\title{
О КОНТРОЛЕ СОСТОЯНИЯ ПОЧВ ВОКРУГ ПТИЦЕВОДЧЕСКИХ ПРЕДПРИЯТИЙ
}

\section{Ольга Алексеевна Напорова}

Сибирский государственный университет геосистем и технологий, 630108, Россия, г. Новосибирск, ул. Плахотного, 10, обучающийся, тел. (960)793-79-37, e-mail: sahnova.o@mail.ru

\section{Евгения Ивановна Баранова}

Сибирский государственный университет геосистем и технологий, 630108, Россия, г. Новосибирск, Плахотного, 10, кандидат технических наук, доцент кафедры экологии и природопользования, тел. (383)361-08-86, e-mail: evg.dxn@yandex.ru

В статье охарактеризовано вредное влияние птицефабрик на окружающую среду. Конкретизировано негативное влияние птицефабрик на состояние почв. Перечислены основные загрязняющие вещества от птицефабрик. Описаны способы утилизации помета. Приведена нормативно-правовая база. Сделан вывод о необходимости специального мониторинга почв вокруг птицефабрик и ужесточении законодательства в области производства и внесения органических удобрений.

Ключевые слова: птицеводческие предприятия, загрязнение окружающей среды, утилизация помёта, микробиологическое загрязнение почв, мониторинг состояния почв, очистные сооружения, законодательство в области охраны окружающей среды

\section{ABOUT CONTROL OF THE STATE OF SOILS AROUND THE POULTRY-BREEDING ENTERPRISES}

\section{Olga A. Naporova}

Siberian State University of Geosystems and Technologies, 10, Plakhotnogo St., Novosibirsk, 630108, Russia, Student, phone: (960)793-79-37, e-mail: sahnova.o@mail.ru

\section{Evgenyia I. Baranova}

Siberian State University of Geosystems and Technologies, 10, Plakhotnogo St., Novosibirsk, 630108, Russia, Ph. D., Assoc. Prof., Department of Ecology and Environmentol Management, phone: (383)361-08-86, e-mail: evg.dxn@yandex.ru

The article describes the harmful effects of poultry farms on the environment. The negative impact of poultry farms on the state of soil is specified. The main pollutants from poultry farms are listed. The methods of litter disposal are described. The regulatory framework is provided. The conclusion is drawn on the need for special monitoring of soils around poultry farms and toughening legislation in the field of production and application of organic fertilizers.

Keywords: poultry enterprises, environmental pollution, litter disposal, soil microbiological pollution, monitoring of soil conditions, treatment facilities, environmental legislation

Работа птицеводческих предприятий, как любая хозяйственная деятельность, сопровождается воздействием на окружающую среду. Птицефабрики воздействуют на все природные компоненты: загрязняют атмосферный воздух, 
сбрасывают сточные воды, образуют отходы производства всех классов опасности и заражают почву.

Цель исследования: рассмотреть виды негативного влияния птицефабрик на окружающую среду.

Задачи: рассмотреть вредные экологические факторы; изучить методы борьбы с загрязнениями; разработать предложения по ужесточению контроля в области утилизации отходов птицефабрик.

Функционирование птицеводческих предприятий всегда сопровождается загрязнением окружающей среды. Основными видами негативного воздействия на окружающую среду являются: сбросы загрязняющих веществ в водные объекты; выбросы в атмосферный воздух; загрязнение почв; размещение отходов; загрязнение шумом, вибрацией, теплом.

Объекты сельскохозяйственного назначения должны иметь необходимые санитарно-защитные зоны и очистные сооружения, исключающие загрязнение почв, поверхностных и подземных вод, водосборных площадей и атмосферного воздуха, согласно статье 42 Ф3-7 [1].

Наиболее эффективным методом очистки выбросов предприятия является использование пылегазоочистных установок.

Оптимальный метод очистки отходящих газов определяется в зависимости от показателей выбросов, таких как: химический состав, агрегатное состояние, масса выброса, размер частиц.

Существует четыре метода очистки газовых выбросов, каждому из которых соответствует определенный очистной аппарат: при механическом методе используют циклоны, фильтры, пылеосадительные камеры, сеточные брызгоулавливатели; при физическом - сухие и мокрые электрофильтры; при термическом печи и горелки; при физико-химическом - адсорберы.

Также на предприятии образуются сточные воды. Их можно использовать повторно (оборотное водоснабжение) или очищать с последующим сбросом в водный объект или централизованную систему водоотведения.

Очистка производственных сточных вод включает четыре метода. При выборе метода очистки учитывается вид удаляемого загрязнения. Основными видами загрязнения сточных вод являются: механическое, химическое, биологическое, радиоактивное и тепловое.

Механический метод очистки производится с помощью решеток, сит, песколовок, отстойников, нефтеловушек, жироловушек, магнитных фильтров, гидроциклонов.

Химический метод осуществляется за счёт окисления в окислительных установках.

Биологический метод основан на направленном воздействии микроорганизмов на загрязнения, для этого используются такие установки как: биопруды, аэротенки, биофильтры.

При очистке физико-химическим методом используются флотаторы, реакторы-отстойники, ионообменные установки, экстракторы. 
Также в результате функционирования птицефабрик образуются отходы производства. Кроме твердых бытовых отходов результатом деятельности птицефабрик являются отходы кормов, отходы убоя и помёт.

Отходы кормов и убоя успешно утилизируются. Главной проблемой птицеводческих предприятий является образование большого количества птичьего помёта. Известно, что птичий помёт является источником развития патогенной микрофлоры. Помёт куриный свежий относится к 3 классу опасности, перепревший - к четвертому [2]. При разложении органических веществ выделяются аммиак, метан, сероводород, окись углерода.

Есть несколько способов утилизации помёта: компостирование, получение биогаза, сжигание. Кроме этого, помёт можно использовать как удобрение, вносить в почву без обработки или после тщательной обработки.

Навоз и куриный помет, используемые для обогащения почвы азотом и другими элементами питания, должны подвергаться предварительному обезвреживанию (термической сушке, компостированию и др.), соответствовать требованиям действующих нормативных документов, не содержать патогенной микрофлоры, в том числе сальмонелл, и жизнеспособных яиц гельминтов [3].

К сожалению, большинство предприятий выдерживает помёт в помётохранилищах, с целью обеспечения процесса компостирования, а затем вывозит на поля и разбрасывает с последующей заделкой в почву. В этом случае удобрительные качества помёта утрачиваются и он превращается в источник заражения патогенными микроорганизмами.

Микробиологические исследования помёта показали, что свежий помёт содержит большое количество условно-патогенных и патогенных бактерий, антропатогенные серотипы кишечной палочки, сальмонеллы [4]. Эти микроорганизмы могут сохраняться в почве до двух лет.

Неправильное внесение птичьего помёта в почву может нанести вред растениям и окружающей природной среде. Внесение свежего помета в почву неэффективно, т.к. не хватает времени для развития микроорганизмов, способных разлагать органическое вещество в формы питания, доступные для растительных организмов [5]. Такие действия предприятия квалифицируются как нарушение законодательства в области охраны окружающей среды и карается штрафами. Согласно КоАП РФ ч. 2 ст. 8.7, невыполнение установленных требований и обязательных мероприятий по улучшению, защите земель и охране почв от ветровой, водной эрозии и предотвращению других процессов и иного негативного воздействия на окружающую среду, ухудшающих качественное состояние земель, - влечет наложение административного штрафа на юридических лиц - от четырехсот тысяч до семисот тысяч рублей [6].

В целом за нарушение законодательства в области охраны окружающей среды устанавливается имущественная, дисциплинарная, административная и уголовная ответственность, согласно статье 75 Ф3-7 [1]. 
Недостаточно отработанные технологии переработки помёта вызывают экологические и экономические издержки. Технологии, применяемые при переработке, должны не только обеззараживать помёт, но и сохранять его удобрительные качества.

В результате проделанной работы разработаны следующие предложения: необходимы разработка новых методов контроля за исполнением законодательных актов, ужесточение законодательства в области производства органических удобрений, увеличение штрафных санкций за загрязнение почв, разработка и внедрение дополнительных схем мониторинга почв вокруг птицефабрик на выявление биологического загрязнения помётом.

\section{БИБЛИОГРАФИЧЕСКИЙ СПИСОК}

1. Федеральный закон от 20.12.2001 N 7-Ф3 «Об охране окружающей среды» [Электронный ресурс] - Режим доступа: http: //docs.cntd.ru/document/901808297.

2. «Об утверждении Критериев отнесения отходов к I-V классам опасности по степени негативного воздействия на окружающую среду». Приказ Министерства приролных ресурсов и экологии РФ РФ от 04.12.2014 N 536 [Электронный ресурс] - Режим доступа: http://docs.cntd.ru/document/420240163.

3. О введении в действие санитарных правил СП 1.2.1170-02 «Гигиенические требования к безопасности агрохимикатов». Постановление Министерства здравоохранения Российской Федерации от 23.10.2002 N 36 Электронный ресурс] - Режим доступа: http://docs.cntd.ru/document/901832979.

4. Лысенко В. П. Переработка отходов птицеводческих хозяйств : учебное пособие / В. П. Лысенко, В. Г. Тюрин. - Москва : ВНИИгеосистем, 2016. - 426 с.

5. Тюрин В. Г. Ветеринарно-санитарная оценка помета / В.Г. Лысенко, В.П. Лысенко. Москва : ВНИИгеосистем , 2009. - $46 \mathrm{c.}$

6. Федеральный закон от 30.12.2001N 195 «Кодекс об административных правонарушениях» [Электронный ресурс] - Режим доступа: http://www. consultant.ru/document/cons_doc_LAW_34661/.

(C) O. A. Напорова, Е. И. Баранова, 2021 